\title{
PENGARUH MOBILISASI DINI TERHADAP PENYEMBUHAN LUKA POST SECTIO CAESARIA PADA IBU POST SECTIO CAESARIA DI RS AURA SYIFA KABUPATEN KEDIRI
}

\author{
Yola Alqorien Mustikarani ${ }^{1}$, Weni Tri Purnani ${ }^{2}$, Miftakhul Mualimah ${ }^{3}$ \\ ${ }^{1}$ Mahasiswa D4 Bidan Pendidik Universitas Kadiri, ${ }^{2,3}$ Dosen Prodi D4 Bidan \\ Pendidik Universitas Kadiri \\ Email : 'yolla.mstika@gmail.com
}

\begin{abstract}
ABSTRAK
Penyembuhan luka merupakan proses kompleks yang melibatkan regenerasi pembentukan jaringan parut epitel dan ikat. Mobilisasi dini penting untuk mengetahui seberapa proses penyembuhan luka khususnya pada ibu yang mengalami post sectio caesaria. Tujuan dari penelitian ini adalah untuk mengetahui pengaruh mobilisasi awal penyembuhan luka post sectio caesaria terhadap maternal post sectio caesaria di rumah sakit Aura Syifa Kabupaten Kediri 2016. Metode penelitian yang digunakan adalah desain penelitian PraEksperimental dengan One Group Pretest-Posttest. Populasi yang diteliti adalah semua wanita yang diobati post sectio caesaria 6 jam pada Juli 2016. Pengambilan sampel menggunakan purposive sampling dan diambil sampel sebanyak 20 responden. Hasil penelitian menunjukkan hampir semua responden yaitu 19 responden menderita penyembuhan luka dengan kategori luka sembuh pada hari ketiga post sectio caesaria atau setelah melakukan mobilisasi dini. Hasil analisis data menggunakan uji Wilcoxon diperoleh nilai $\rho(0,000)<\alpha(0,05)$. Ada pengaruh mobilisasi awal penyembuhan luka post sectio caesaria pada maternal post sectio caesaria di rumah sakit Aura Kabupaten Kediri Betterbydrbrooke 2016. Tenaga kesehatan yang diharapkan dapat meningkatkan profesionalisme dalam memberikan layanan kepada pasien, terutama dalam memberikan mobilisasi dini pasca sectio caesaria.
\end{abstract}

Kata Kunci : Mobilisasi Dini, Penyembuhan luka, Post sectio caesaria

\begin{abstract}
Wound healing is a complex process which involves regeneration of epithelial and connective tissue scar formation. Based on the survey, 3 out of 5 patients with the condition of the wound has not healed. The purpose of this research is to know the influence of early mobilization wound healing post sectio caesaria on maternal post sectio caesaria in hospital the Aura Syifa of Kediri Regency 2016. The research method used was Pre-Experimental research designs with One Group Pretest-Posttest. The population examined was all women treated post sectio caesaria 6 hours in July 2016. Sampling using a purposive sampling and retrieved samples of 20 respondents. The results showed nearly all of the respondents that is 19 respondents suffered a wound healing by category healed wounds on the third day post sectio caesaria or after performing early mobilization. The results of the analysis of the data using the Wilcoxon test obtained the value of $\rho$ value $(0.000)<\alpha(0.05)$. There is the influence of early mobilization wound healing post sectio caesaria on maternal post sectio caesaria in hospital the Aura of Kediri Regency Betterbydrbrooke 2016. Expected health
\end{abstract}


workers to increase professionalism in providing services to patients, especially in providing early mobilization post sectio caesaria.

Keywords: post sectio caesaria, wound healing, early mobilization

\section{PENDAHULUAN}

Masa nifas (puerperium) merupakan masa kritis baik ibu maupun bayinya. Diperkirakan bahwa $60 \%$ kematian ibu akibat kehamilan terjadi setelah persalinan, dan $50 \%$ kermatian masa nifas terjadi dalam 24 jam pertama (Rukiyah, 2011).

Menurut WHO di seluruh dunia setiap menit seorang perempuan meninggal karena komplikasi terkait dengan kehamilan dan nifas. Dengan kata lain 1.400 perempuan meninggal setiap hari atau lebih dari 500.000 perempuan meninggal setiap tahun karena kehamilan, persalinan, dan nifas (Dalila, 2015).

Angka kematian ibu (AKI) di Indonesia masih tertinggi di negara ASEAN. Penyebab langsung kematian ibu di Indonesia dan negara lainnya di dunia hampir sama yaitu akibat perdarahan (28\%), eklampsia (24\%), dan infeksi (11\%). Sementara penyebab tidak langsung kematian ibu antara lain kurang energi kronis pada kehamilan $(37 \%)$ dan anemia pada kehamilan (40\%) (Determinan et al., 2012).

Salah satu cara untuk mencegah AKI adalah dilakukannya tindakan Sectio Caesaria (SC). WHO memperkirakan bahwa angka persalinan dengan bedah Caesaria adalah sekitar $10 \%$ sampai $15 \%$ dari semua proses persalinan di negaranegara berkembang. Tindakan insisi pada persalinan sectio caesarea ini menyebabkan luka sayat yang harus diperhatikan derajat kesembuhan lukanya karena risiko tinggi terjadi infeksi, rupture uteri dan perdarahan. Salah satu hal yang berperan pada proses penyembuhan luka adalah mobilisasi dini yang dipercaya dan terbukti dapat meningkatkan proses penyembuhan luka (World Health
Organization Human Reproduction Programme, 2015).

Di Indonesia, bedah sesar hanya dilakukan atas dasar indikasi medis tertentu dan kehamilan dengan komplikasi. Hasil Riskesdas 2013 menunjukkan kelahiran bedah sesar sebesar 9,8\%. Proporsi persalinan sesar di provinsi Jawa Timur sebesar 10,2\% dari total persalinan (Badan Penelitian dan Pengembangan Kesehatan, 2013)

Studi pendahuluan yang dilakukan di RS Aura Syifa Kabupaten Kediri, didapatkan angka kejadian kelahiran secara Sectio Caesaria sebesar 1.410 dari 2983 kelahiran (47,27\%). Angka kelahiran secara Sectio Caesaria terbilang cukup tinggi dengan perbandingan dengan persalinan normal sebesar 1560 kelahiran $(52,30 \%)$ dan persalinan dengan vacum ektraksi sebesar 13 kelahiran $(0,43 \%)$ dari 2983 kelahiran. Saat peneliti melakukan wawancara kepada 5 pasien post sectio caesaria di Ruang Nifas Rumah Sakit Aura Syifa Kabupaten Kediri, dari 5 pasien 3 diantaranya mengatakan tidak melakukan mobilisasi dini karena takut sakit pada luka post sectio caesaria dan tidak mengetahui tentang pentingnya melakukan mobilisasi dini post sectio caesaria dengan kondisi luka yang masih merembes pada hari ke 3 dan luka belum kering. Dua pasien lain mengatakan sudah berusaha melakukan aktivitas dengan menggerakkan anggota tubuh semampunya dengan kondisi luka pada hari ke 3 sudah membaik, tidak ada warna kemerahan dan luka sudah mulai mengering. Hal ini menunjukkan masih banyak pasien post sectio caesaria yang tidak melakukan mobilisasi dini dan dengan kondisi luka yang tidak baik.

Berdasarkan fenomena tersebut peneliti tertarik untuk mengambil penelitian tentang pengaruh mobilisasi dini terhadap penyembuhan luka post sectio 
caesaria ada ibu post sectio caesaria di RS Aura Syifa Kabupaten Kediri tahun 2016.

\section{METODE PENELITIAN}

Jenis penelitian yang digunakan dalam penelitian ini adalah penelitian penelitian pre eksperimental dengan pendekatan one group pretest posttest design. Populasi dalam penelitian ini adalah semua ibu post sectio caesaria 6 jam di ruang nifas RS Aura Syifa Kabupaten Kediri pada bulan Juli 2016. Sampel pada penelitian ini adalah sebagian ibu post sectio caesaria 6 jam di ruang nifas RS Aura Syifa Kabupaten Kediri pada bulan Juli 2016 sebanyak 20 responden.

Instrumen yang digunakan dalam variabel ini adalah lembar observasi penyembuhan luka pasca operasi untuk mengumpulkan data pasien sebelum dan sesudah diberikan perlakuan menggunakan skala guttman yaitu observer memilih alternatif jawaban ya dan tidak, sesuai dengan keadaan pasien. Apabila "Ya" diberi skor 1 dan "Tidak" diberi skor 0 .

Analisis Data yang digunakan adalah analisis univariat Analisis univariat hanya menghasilkan distribusi frekuensi dan bivariat dengan uji Wilcoxon.

\section{HASIL DAN PEMBAHASAN}

Tabel 1 Distributsi Frekuensi Karakteristik Responden Berdasarkan Usia Ibu Post Sectio Caesaria di Rumah Sakit Aura Syifa Kabupaten Kediri Tahun 2016

\begin{tabular}{|c|c|c|c|c|c|}
\hline Usia & Frekuensi & Persentase (\%) & \multirow{4}{*}{\multicolumn{3}{|c|}{$\begin{array}{l}\text { Tabel } 4 \text { Distribusi Frekuensi Penyembuhan } \\
\text { Luka Post Sectio Caesaria pada Ibu Post } \\
\text { Sectio Caesaria di Rumah Sakit Aura Syifa } \\
\text { Kabupaten Kediri Tahun } 2016\end{array}$}} \\
\hline$<20$ Tahun & 1 & 5 & & & \\
\hline 20-35 Tahun & 16 & 80 & & & \\
\hline$>35$ Tahun & 3 & 15 & & & \\
\hline Total & 20 & 100 & Penyembuhan & Frekuensi & $\begin{array}{c}\text { Persentase } \\
(\%)\end{array}$ \\
\hline \multicolumn{3}{|c|}{ Sumber : Data Primer 2016} & Luka Sembuh & 0 & 0 \\
\hline \multirow{2}{*}{\multicolumn{3}{|c|}{$\begin{array}{l}\text { Berdasarkan Tabel } 1 \text { di atas dapat } \\
\text { pretasikan yaitu hampir seluruhnya }\end{array}$}} & $\begin{array}{l}\text { Luka Belum } \\
\text { Sembuh }\end{array}$ & 20 & 100 \\
\hline & & & Total & 20 & 100 \\
\hline
\end{tabular}

Tabel 2 Distributsi Frekuensi Karakteristik Responden Berdasarkan Pendidikan Ibu Post Sectio Caesaria di Rumah Sakit Aura Syifa Kabupaten Kediri Tahun 2016

\begin{tabular}{ccc}
\hline Pendidikan & Frekuensi & $\begin{array}{c}\text { Persentase } \\
(\mathbf{\%})\end{array}$ \\
\hline SD & 0 & 0 \\
SMP & 3 & 15 \\
SMA & 13 & 65 \\
Akademi/PT & 4 & 20 \\
\hline Total & $\mathbf{2 0}$ & $\mathbf{1 0 0}$ \\
\hline
\end{tabular}

Sumber : Data Primer 2016

Berdasarkan Tabel 2 di atas dapat diinterpretasikan yaitu sebagian besar (65\%) responden berjumlah 13 orang berpendidikan Sekolah Menengah Atas.

Tabel 3. Distribusi Frekuensi Karakteristik Responden Berdasarkan Paritas Ibu Post Sectio Caesaria di Rumah Sakit Aura Syifa Kabupaten Kediri Tahun 2016

\begin{tabular}{ccc}
\hline Paritas & Frekuensi & $\begin{array}{c}\text { Persentase } \\
(\mathbf{\%})\end{array}$ \\
\hline Primipara & 7 & 35 \\
Multipara & 13 & 65 \\
Grandepara & 0 & 0 \\
\hline Total & $\mathbf{2 0}$ & $\mathbf{1 0 0}$ \\
\hline
\end{tabular}

Sumber : Data Primer 2016

Berdasarkan Tabel 3 di atas dapat diinterpretasikan yaitu sebagian besar (65\%) responden berjumlah 13 orang merupakan multipara. berusia 20-35 tahun. 
Berdasarkan data yang diperoleh dari Tabel 4 ddpat diinterpretasikan bahwa pada seluruh responden memiliki kondisi luka belum sembuh pada hari pertama sebelum dilakukan mobilisasi dini yaitu sebanyak $20(100 \%)$ responden.

Berdasarkan data yang diperoleh dari Tabel 5 dapat dinterpretasikan bahwa hampir seluruh responden sembuh yaitu sebanyak 19 (95\%) responden, dengan responden mampu melakukan semua gerakan mobilisasi dini post sectio caesaria
Tabel 5 Distribusi Frekuensi Penyembuhan Luka Post Sectio Caesaria Pada Ibu Post Sectio Caesaria di RS Aura Syifa Kabupaten Kediri Tahun 2016

\begin{tabular}{ccc}
\hline Penyembuhan & Frekuensi & $\begin{array}{c}\text { Persentase } \\
(\mathbf{\%})\end{array}$ \\
\hline Luka Sembuh & 19 & 95 \\
Luka Belum & 1 & 5 \\
Sembuh & & \\
\hline Total & $\mathbf{2 0}$ & $\mathbf{1 0 0}$ \\
\hline
\end{tabular}

Tabel 6 Penyembuhan Luka Post Sectio Caesaria pada Ibu Post Sectio Caesaria sebelum dan Sesudah Mobilisasi Dini di Rumah Sakit Aura Syifa Kabupaten Kediri Tahun 2016

\begin{tabular}{llrrrr} 
& & \multicolumn{2}{c}{ Sesudah } & \multirow{2}{*}{ Total } \\
\cline { 3 - 4 } & & Luka Belum & \\
\hline \multirow{2}{*}{ Sebelum } & Luka Belum & Jumlah & 19 & 1 & 20 \\
\cline { 3 - 5 } Total & Sembuh & Prosentase & $95,0 \%$ & $5,0 \%$ & $100,0 \%$ \\
& & Jumlah & 19 & 1 & 20 \\
& & $95,0 \%$ & $5,0 \%$ & $100,0 \%$ \\
& & Prosentase & $p$-value $=0,000 ; \alpha=0,05$ & & \\
\hline
\end{tabular}

Sumber : Data Primer 2016

Berdasarkan data yang diperoleh dari tabel 6 dapat diinterpretasikan bahwa mobilisasi dini berpengaruh terhadap penyembuhan luka post sectio caesaria dengan hampir seluruh responden mengalami penyembuhan luka post sectio caesaria dengan kategori luka sembuh dalam waktu 3 hari setelah melakukan mobilisasi dini yaitu sebanyak 19 (95\%) responden.

Berdasarkan hasil uji statistik dengan menggunakan uji wilcoxson diketahui bahwa besarnya nilai $p$-value 0,000 lebih kecil dari nilai $\alpha=0,05(.000<$ $0,05)$ sehingga $\mathrm{H}_{0}$ ditolak dan $\mathrm{H}_{1}$ diterima, artinya ada pengaruh mobilisasi dini terhadap penyembuhan luka post sectio caesaria pada ibu post sectio caesaria di Rumah Sakit Aura Syifa Kabupaten Kediri Tahun 2016.

\section{Penyembuhan Luka Post Sectio Caesaria Sebelum dilakukan Mobilisasi Dini \\ Penyembuhan luka adalah suatu} proses yang kompleks dan umumnya terjadi secara teratur yang melibatkan regenerasi epitel dan pembentukan parut jaringan ikat. Penyembuhan luka akan melibatkan proses fisiologis. Sebenarnya sifat penyembuhan dari semua luka adalah sama, hanya ada beberapa hal yang membedakan yaitu bergantung pada lokasi, tingkat keparahan, dan luasnya luka. Namun yang paling menentukan adaah kemampuan sel untuk beregenerasi (kembali ke struktur normal). Luka setelah dilakukan pembedahan sectio caesaria akan megalami proses penyembuhan luka yang terdiri dari 3 fase, yaitu fase inflamasi, fase proliferasi, dan fase maturasi (Arimina Hartati Pontoh, 2013).

Fase penyembuhan luka diawali dengan fase inflamasi. Fase ini dimulai 
dari adanya reaksi tubuh terhadap luka dimulai dari beberapa menit setelah cedera dan berlangsung selama beberapa hari. Dalam fase ini terjadi proses hemostatis (pengontrolan perdarahan) yaitu sesuai dengan perintah otak, tubuh akan mengirim suplai darah ke area yang mengalami cedera, kemudian membentuk sel-sel epitel (epitelialisasi) (Potter, 2011).

Selama proses ini pembuluh darah yang menyuplai darah ke area luka akan mengalami kontriksi dan trombosit akan berkumpul di area luka untuk menghentikan proses perdarahan dengan membentuk jaring-jaring benang fibrin (matriks fibrin) dari matriks fibrin inilah yang nantinya akan menjadi kerangka perbaikan sel. Kemudian jaringan yang rusak menyekresi histamin yang merangsang vasodilatasi kapiler di area luka dan mengeluarkan serum dan sel darah putih (Potter, 2011).

Kedua komponen ini akan menyebabkan inflamasi guna membunuh kuman penyakit yang mungkin ada saat luka terjadi. Proses inflamasi ini tentunya akan menyebabkan tanda inflamasi berupa kemerahan, bengkak, hangat, dan nyeri lokal (Potter, 2011).

Berdasarkan hal diatas dapat dijelaskan bahwa sebelum diberikan perlakuan berupa mobilisasi dini, responden berada di fase inflamasi. Pada fase ini luka belum menutup karena belum adanya pertumbuhan jaringan penyambung (granulasi) yang baru untuk menutup luka. Sehingga masih dibutuhkan waktu untuk penyembuhan luka.

\section{Penyembuhan Luka Post Sectio Caesaria Sesudah Dilakukan Mobilisasi Dini}

Mobilisasi dini merupakan gerakan sistematis yang dilakukan oleh ibu pasca persalinan baik persalinan normal maupun persalinan dengan tindakan. mobilisasi dini pada ibu post sectio caesaria dilakukan secara bertahap mulai 6 jam pasca persalinan. Gerakan-gerakan dalam mobilisasi dini tersebut dapat membantu pemulihan ibu pasca persalinan. Ambulasi dini dapat membantu pasien dalam menghindari morbiditas dan meningkatkan pemulihan awal pasien (Dube, 2014).

Mobilisasi dini adalah salah satu faktor yang mempengaruhi kesembuhan luka pasca bedah serta dapat mengurangi resiko komplikasi. Mobilisasi dni sangat penting dalam percepatan hari rawat dan mengurangi resiko-resiko karena tirah baring lama seperti kekakuan/penegangan otot-otot di seluruh tubuh dan sirkulasi (Mubarak, 2008; Ditya, 2016)

Berdasarkan hasil penelitian diatas, bahwa mobilisasi dini dapat berpengaruh pada penyembuhan luka post sectio caesaria karena mobilisasi dini dapat meningkatkan kelancaran peredaran darah sehingga nutrisi yang dbutuhkan luka terpenuhi dan mempercepat kesembuhan luka. Penelitian dilakukan pada hari ke tiga post sectio caesaria yaitu pada fase proliferasi. Didapatkan satu responden yang melakukan mobilisasi dini dengan baik tapi penyembuhan luka dalam kondisi belum sembuh, hal ini diketahui pada saat penggantian kassa perut pada hari ke 3 ditemukan luka belum kering dan belum menyatu.

Kondisi tersebut diduga karena faktor usia dan nutrisi karena peneliti tidak mampu mengontrol responden secara penuh baik dari segi kegiatan, segi pola makan dan jenis makanan responden sehari-hari. Usia ibu sudah $>35$ tahun sehingga kelembapan kulit berkurang yang dapat mempengaruhi penurunan elastisitas kulit. Selain itu, semakin menua kandungan kolagen dalam kulit juga mengalami penurunan sehingga proses regenasi sel baru menjadi terhambat. Hal ini tentu saja dapat mempengaruhi proses penyembuhan luka post sectio caesaria (Boyle, 2009).

Nutrisi juga mempengaruhi proses penyembuhan luka, dimana kurangnya asupan protein merupakan penyebab yang sangat penting dari lambatnya penyembuhan luka. Adanya responden yang masih merasa takut untuk makan makanan yang mengandung protein yang diberikan sehingga pasien tidak memenuhi 
kebutuhan nutrisi yang telah disediakan oleh rumah sakit, padahal justru proteinlah yang sangat dibutuhkan oleh luka untuk proses pemulihan dan penggantian sel sel yang mati akibat pembedahan (Boyle, 2009).

\section{Pengaruh Mobilisasi Dini Terhadap Penyebuhan Luka Post Sectio Caesaria}

Secara teoritis kesembuhan luka merupakan suatu proses pergantian jaringan yang mati atau rusak dengan jaringan yang baru dan sehat oleh tubuh dengan jalan regenerasi. Luka dikatakan sembuh apabila permukaannya dapat bersatu kembali dan didapatkan kekuatan jaringan yang kembali normal. Kesembuhan luka meliputi 2 kategori yaitu: pemulihan jaringan ialah regenerasi jaringan pulih seperti semula baik secara struktur maupun secara fungsinya, dan repair ialah pemulihan atau penggantian oleh jaringan ikat (Purwatiningtyas, 2013)

Usia merupakan salah satu faktor yang mempengaruhi penyembuhan luka post sectio caesaria. Semakin tua usia ibu post sectio caesaria akan semakin lama dalam proses penyembuhan luka. Hal ini dipengaruhi oleh penurunan elastin dalam kulit dan perbedaan penggantian kolagen mempengaruhi penyembuhan luka. Usia ibu yang hampir seluruhnya diantara 20-35 tahun sangat berpengaruh terhadap penyembuhan luka. Pada usia tersebut kondisi kulit ibu masih masih elastis dan dapat memproduksi banyak kolagen sehingga dapat mempengaruhi penyembuhan luka. (Boyle, 2009; Hamilton, 2010).

Selain usia pendidikan juga mempengaruhi penyembuhan luka pada ibu post sectio caesaria. Pendidikan berpengaruh pada tingkat pengetahuan ibu, baik secara gizi, sikap maupun secara perawatan lainnya. Pengetahuan sangat erat hubungannya dengan pendidikan, dimana diharapkan bahwa dengan pendidikan yang tinggi maka orang tersebut akan semakin luas pengetahuannya (Dewi, 2011).
Paritas juga salah satu hal yang berpengaruh dari penyembuhan luka. Ibu yang pernah mengalami seksio sesaria sudah lebih mengenal dampak dari mobilisasi dini, sehingga dengan edukasi minimal sudah mampu melakukannya dengan baik. Mobilisasi dini jika dilakukan dengan baik serta perawatan yang baik maka akan membantu penyembuhan luka post sectio caesaria, sehingga dapat mencegah terjadinya infeksi pada luka. Terdapat kecenderungan pengetahuan ibu dengan paritas tinggi lebih baik dari pengetahuan ibu dengan paritas rendah (Notoatmodjo, 2010; Kanti, 2012).

\section{KESIMPULAN}

Pada penelitian ini, didapatkan beberapa saran, antara lain Penyembuhan luka sebelum dilakukan mobilisasi dini di Rumah Sakit Aura Syifa Kabupaten Kediri Tahun 2016 yaitu seluruh responden memiliki kondisi luka belum sembuh. Penyembuhan luka setelah dilakukan mobilisasi dini di Rumah Sakit Aura Syifa Kabupaten Kediri Tahun 2016 yaitu hampir seluruh responden memiliki kondisi luka sembuh. Hasil uji Wilcoxon terdapat pengaruh mobilisasi dini terhadap penyembuhan luka post sectio caesaria pada ibu post sectio caesaria di Rumah Sakit Aura Syifa Kabupaten Kediri Tahun 2016 dilihat dari luka yang sembuh tepat pada waktunya.

Berdasarkan kesimpulan yang didapat dari penelitian ini, terdapat beberapa saran antara lain: 1) Bagi tempat penelitian hasil penelitian ini mampu menjadi pertimbangan pihak rumah sakit dalam pembuatan Standar Prosedur Operasional (SOP) monilisasi dini post sectio caesaria. hypnobirthing di fasilitas kesehatan, 2) Bagi petugas kesehatan mampu meningkatkan profesionalisme dalam memberikan pelayanan kepada pasien khususnya dalam memberikan mobilisasi dini post sectio caesaria. 3) Bagi peneliti selanjutnya dapat meneliti mengenai hypnobirthing dengan responden yang cakupannya lebih spesifik dan jumlah 
responden yang lebih besar dengan jenis penelitian yang lebih baik.

\section{DAFTAR PUSTAKA}

Arimina, P.H. (2013) 'Pengaruh mobilisasi dini terhadap penyembuhan luka sectio caesaria', Jurnal Kebidanan Griya Husada Surabaya, (110), pp. 118-124. doi: 10.22216/jit.2017.v11i1 .661.

Badan Penelitian dan Pengembangan Kesehatan. (2013). 'Riset Kesehatan Dasar (RISKESDAS) 2013', Laporan Nasional 2013, pp. 1-384. doi: 1 Desember 2013.

Boyle, M. (2009). Pemulihan Luka. Jakarta: EGC.

Dalila, S. (2015) 'Pengaruh Senam Nifas Terhadap Penguatan Otot Perut Ibu Postpartum'.

Determinan, K. et al. (2012) 'Akses \& kualitas'.

Dewi. (2011). Asuhan Kebidanan Pada Ibu Nifas. Jakarta: Salemba Medika

Ditya, M. and Zahari, A. (2016) 'Hubungan Mobilisasi Dini dengan Proses Penyembuhan Luka Artikel Penelitian', Jurnal Kesehatan Andalas, 5(3), pp. 724-729.

Dube, J. V and Kshirsagar, N. S. (2014) 'Effect of planned early recommended ambulation technique on selected post caesarean biophysiological health parameters', Journal of Krishna Institute of Medical Sciences University, 3(1), pp. 41-48. Available at: https://www.scopus. com/inward/record.uri?eid=2-s2.084905921720\&partnerID=40\&md5=669ca881e7764db863b4c050c2609622.

Hamilton. (2010). Mobilisasi Dini. Jakarta: Salemba Medika.

Mubarak, M.I. (2008). Buku Ajar Kebutuhan Dasar Manusia Teori dan Aplikasi dalam Praktek. Jakarta: EGC.

Notoatmodjo, S. (2010). Metodologi Penelitian Kesehatan. Jakarta: Rineka Cipta.

Potter, P., Perry, A. (2011). Fundamental Keperawatan Vol. 3 Edisi 7. USA: Mosby Elsevier.

Purwatiningtyas, R. (2013). Hubungan Riwayat SC dengan Penyembuhan Luka Post Sectio Caesaria di Irna C RSUD Syarifah Ambami Rato Ebhu Bangkalan. Bangkalan: STIKes Insan Se Agung Bangkalan.

Rukiyah. (2011). Asuhan Kebidanan. Jakarta: Trans Info Media.

World Health Organization Human Reproduction Programme, 10 April 2015 (2015) 'WHO Statement on caesarean section rates.', Reproductive health matters, 23(45), pp. 149-50. doi: 10.1016/j.rhm.2015.07.007. 